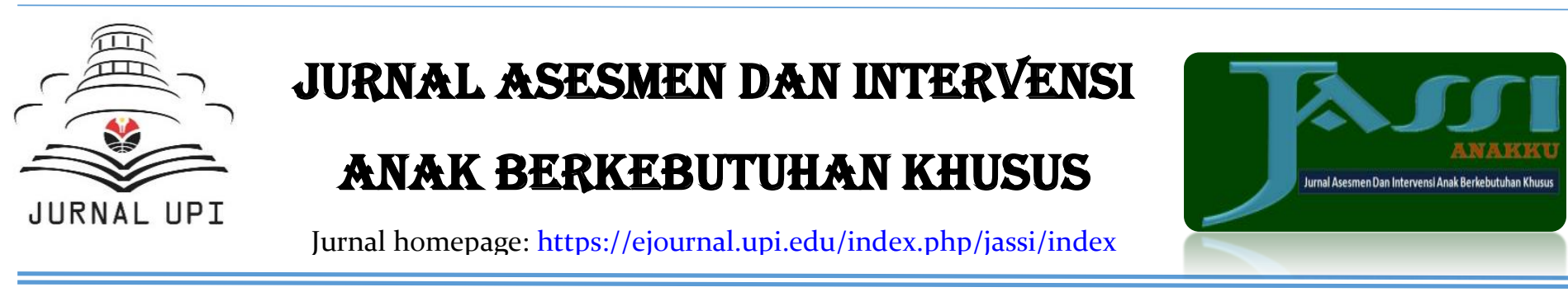

\title{
Green Inclusive: Efforts to Create an Inclusive Environment Through Gardening Activities with Children with Special Needs
}

Nur Aminah*, Fina Rahma Fauziah, Jihan Fatin, Sri Garcinia Lathifah, Wildan Madani, Oom Sitti Homdijah

Universitas Pendidikan Indonesia, Indonesia

*Correspondence: E-mail: nuraminah@upi.edu

\section{A B S T R ACTS}

Activity partners selected in this service activity were selected using a purposive sample system (subjective sample intended based on the researcher's assessment). Based on observations and informal interviews with partners and the community in Kawali Village, Ciamis, Indonesia, the empowerment of children with special needs and the community through gardening activities in the village is very necessary for land use, increasing productivity, and efforts to create an inclusive community environment. The techniques are counseling, webinars, questions and answers, the direct object method of gardening with special needs children, child gardening at home, learning active methods, descriptive interviews, and practices related to gardening activities. The results of the study are: (1) an increase in public knowledge regarding the child with special needs, (2) creating a friendly environment for crew members, (3) publication of activities published in popular media, and (4) design of sustainable targets for further activities. This community service activity has a good impact and a positive value because the series of activities carried out can be a means of improving a friendly environment for children with special needs, and providing useful knowledge to the Kawali, Ciamis, Indonesia.

\author{
ART ICLE INF O \\ Article History: \\ Received 8 Feb 2021 \\ Revised 12 May 2021 \\ Accepted 14 May 2021 \\ Available online 16 May 2021
}

\section{Keyword:}

Children with special needs,

Gardening,

Inclusive Community. 


\section{INTRODUCTION}

Children with special needs are children who require special education services that are tailored to the potential, obstacles, and learning needs of children because they are different from children in general. The Ministry of Women's Empowerment and Child Protection (Kemen PPPA) of the Republic of Indonesia 2013, explains that children with special needs are children who experience limitations or extraordinariness, both physical, mental-intellectual, social, and emotional, which have a significant effect on the process of growth or development compared to other kids his age.

Children with special needs can be classified into several barriers such as children with visual impairments, hearing impairments, intellectual, physical, emotional barriers, and so on with different characteristics of each obstacle. According to Government Regulation No. 17 of 2010 article 129 paragraph (3) classification of Children with special needs consists of a) visually impaired; b) deaf; c) mute; d) mental retardation; e) quadriplegic; f) tuning; g) learning difficulties; h) slow learners; i) autism; j) have motor impairments; k) become a victim of abuse of narcotics, illegal drugs, and other addictive substances; I) have other disorders. So, several barriers can be seen that children with special needs are not only children who have physical disabilities, but children who have intellectual and social weaknesses are also included in children with special needs. However, even though they have the same obstacles, their characteristics are certainly different from one another and cannot be generalized.

Children with special needs in their lives in the community are often treated inappropriately, such as still finding discriminatory attitudes towards children, being afraid when interacting with children, or even seeing them as strange and disturbing as well as dangerous. Not only that, but children with special needs are also often seen as weak and need to be pitied. This makes the community inharmonious and the environment is not inclusive or friendly to crew members, and individual diversity is not accepted. Based on field studies and interviews with several community members in Kawali Village, Ciamis, Indonesia, it was found that many people did not know Children with special needs and how to interact and communicate, so that children with special needs was often ignored. And it is still found that children with special needs parents do not give their children the opportunity to interact with the outside world due to the attitude of the surrounding community which is often not friendly to children.

Based on law no. 8 of 2016 that explains the legal basis for persons with disabilities, it is the government's efforts to fulfill disability rights in education and health. Therefore, the main problem is related to the absence of an inclusive society in the Kawali Village, Indonesia area which makes the neglect of children with special needs in the area reflected by disharmony in children with special needs such as avoiding and fear behavior, because they feel that children with special needs are different and so on. Therefore, there needs to be a change in this matter, so that crew members can be accepted in their environment. Such as by conducting joint activities with children with special needs involving local communities and collaborating with local forums. This becomes very important to continue to be promoted so that there is a growing acceptance of diversity in the wider community (Bailey \& Plessis, 2006).

Empowering crew members in an activity that can involve the wider community is one of the efforts that can be used to create an inclusive environment, one of which is gardening activities. Gardening activities have an expected goal for children with special needs according to minimize disturbances or negative behavioral stimuli by leading to improving children's 
welfare in cognitive, physical, social, emotional, and spiritual aspects which in its implementation need supervision and guidance by parents, educators, and therapists.

The benefits derived from gardening activities are improving fine and gross motor skills, improving communication and social skills, increasing self-esteem, and a sense of responsibility increasing the stimulus for sensory perception, creativity, and curiosity. Even with gardening activities, children with special needs can learn to accept and make peace with reality. If, for example, the plants in the garden do not grow as expected, then the child can learn to observe how the plants should grow by learning things that affect them gradually. Most children, including children with special needs, are most likely to succeed when they are directly involved in gardening activities rather than just academic learning or theory in the form of explanations. The selection of the type of plant used needs to be considered, it is better to choose plants that grow fast with a short planting period such as kale, tomatoes, mustard greens, and others. The results of gardening are expected to meet the economic needs of the house and can be of productive value in the future.

According to Village Law Number 6 of 2014 it is explicitly explained that villages are trying to turn villages into inclusive villages. An inclusive village means a village that provides equal opportunities to all citizens to be able to gain access, participation, control, and development benefits (Ra'is, 2017). Increasing welfare through village economic development is one of the passions carried out by the village law. In Permendesa No. 13 of 2020, there are village development priorities set out in the 18 Village Sustainable Development Goals. In it, there are villages without inequality and peaceful villages with justice set out in the Village Sustainable Development Goals, this is the embodiment of an inclusive village.

\section{METHODS}

The method used in problem solving in determining partners, the implementing team applies a purposive sample technique so that the selected partner is the result of the implementation team's assessment. In this case, the implementing team chose Karang Taruna as a partner, because Karang Taruna is a non-profit organization that is closely related to social movement activities. Then after determining partners, the team conducted observations and interviews with partners and the community in Kawali Village, Indonesia.

Based on the results of observations and informal interviews that have been carried out, it can be concluded that the empowerment of children with special needs and the Kawali Village Community through gardening activities is very necessary, this is supported by the following reasons. First, most of the people of Kawali Village, Indonesia still do not fully understand what children with special needs is, the types of children with special needs, and how to treat children with special needs in a friendly manner, so that socialization and education activities in the form of counseling are needed so that people can be more friendly and care about the presence of children with special needs in their environment; Second, there is often ridicule aimed at children with special needs so that it reduces self-confidence and self-esteem of children with special needs to be productively involved in activities outside the home environment, therefore activities are needed that can unite the community and children with special needs by carrying out activities productive together.

The method or technique used in this community service activity is the blended method, which is a combination of direct activities in the field and online activities. Direct activities in the field are in the form of counseling, home visits for children with special needs gardening from home, gardening with children with special needs, comparative studies, building seed houses, licensing and coordination with partners and related parties, buying tools, and 
community literacy. Meanwhile, online activities include organizing Webinar series related to crew members through the Zoom Meetings platform, coordinating activities through the Online Citizen Forum Group.

The use of techniques and methods that have been carried out is expected to make the community and crew members able to be more productive together. So, it is hoped that an inclusive environment will be created in accordance with Village Sustainable Development Goals Number 10 and 16, namely Villages Without Gap and Villages of Peace with Justice.

\section{RESULTS AND DISCUSSION}

The results achieved by the implementing team together with community partnerships with the blended implementation method between field activities and network activities obtained the following results:

\subsection{Socialization of Green Inclusive to Kawali Village Community}

This socialization was carried out by the community service implementation team for partner groups and the community in Kawali village, Indonesia on June 22, 2021. Approximately 45 people attended to get socialization about the concept of children with special needs, inclusive society, and gardening in the form of using yardland. In this socialization activity, the material was given by three speakers. The socialization activity was carried out by complying with strict health protocols and also receiving supervision from local village officials because it was still in a state of the COVID-19 pandemic. Besides being given socialization, the community also received a brochure about Green Inclusive. Based on the results of this activity, the community felt the benefits where they got knowledge about previously unknown crew members and as a manifestation of an inclusive society, as well as gardening activities that could be linked to this goal.

\subsection{Green Inclusive Literacy to the Community}

This activity is an additional activity where the implementing team distributes literacy brochures about children with special needs, inclusive communities, and gardening. The Green Inclusive literacy activity was carried out twice, namely on July 25, 2021, and September 12, 2021, at the car-free day activity in Kawali village, Indonesia. This activity was carried out to achieve an inclusive society as a whole because the activity was carried out during the pandemic so that not all members of the community had access to this information. Based on this literacy activity, almost $90 \%$ of the community still does not know who children with special needs is and how to interact with them, the community becomes aware of and can apply inclusive values when meeting with children with special needs.

\subsection{Gardening from Home with Children with Special Needs}

This activity is carried out as an effort to develop the potential of children with special needs. Before the introduction of limited face-to-face activities at school, children often felt bored at home. The lack of activities that children can do at home makes children often have tantrums because the energy that should be released through physical activity cannot be expended. Gardening activities are expected to channel the energy possessed by children in positive activities. children with special needs gardening activities at home are expected to unlock children's potential in vocational activities so that they can become productive activities. Through this activity, children with special needs has a responsibility and a sense of 
caring for the plants he grows adds a sense of happiness and releases positive energy through gardening activities.

\subsection{Online Seminar Activities (Webinars)}

The seminar activities on the network are carried out in collaboration with several lecturers at the Indonesian Education University and several communities who care about children with special needs and the environment, such as the Indonesian Gardening Community, Earth with Disabilities, and Cikal Inclusive Education. This activity was carried out three times with special participants, namely the people of Kawali village, Indonesia and generally people throughout Indonesia. This activity was attended by hundreds of participants from all over Indonesia, with the implementation through media zoom meetings and live broadcasts on the Green Inclusive YouTube channel. This webinar activity received great enthusiasm and received positive feedback. Many are waiting for this webinar activity with relevant and useful topics to add insight about crew members and an inclusive environment. The themes discussed in the webinar include:

1) Empowerment of children with special needs through gardening activities as an effort to create an inclusive environment on July 3, 2021.

2) Start gardening from home, create a friendly environment with children with special needs on July 17, 2021.

3) The application of inclusive values within the school scope to create a friendly environment for children with special needs on August 14, 2021.

\section{CONCLUSION}

This community service activity can have a positive impact. This is because the series of activities carried out can be a means of improving a friendly environment for children with special needs and provide useful knowledge for the people of Kawali Village, Indonesia, about the community of children with special needs, inclusive communities, gardening procedures and good land use. This is because the majority of people have a large yard, so it can be used as a source of income for the people of Kawali Village, Indonesia. This will create a harmonious, prosperous, and inclusive society.

Suggestions in implementing this Green Inclusive activity is that it is hoped that this activity can be continued with other partners. In addition, the participation of educational institutions and government agencies is highly expected so that the people of Kawali Village, Indonesia and generally the Indonesian people can be educated and more friendly to crew members to create an inclusive environment.

\section{ACKNOWLEDGMENTS}

The author would like to thank the Directorate General of Learning and Student Affairs, Ministry of Research and Technology of the Republic of Indonesia who has provided funding for the Student Creativity Program (PKM) proposal with a community service scheme so that this activity can be carried out properly. In addition, the authors also thank the Karang Taruna Linggawastu in Kawali Village as partners, the Camat of Kawali District, Indonesia; the Head of Kawali Village, Indonesia; the Agricultural Extension Agency of Kawali District, Indonesia; and various parties who have been involved and supported the continuity of this service activity. The author also does not forget to thank the Universitas Pendidikan Indonesia, as well as the lecturers who have been willing to become resource persons in this activity. 


\section{AUTHORS' NOTE}

The authors declare that there is no conflict of interest regarding the publication of this article. The authors confirmed that the paper was free of plagiarism.

\section{REFERENCES}

Bailey, J. and Plessis, D. (2006). Understanding principals' attitudes towards inclusive schooling. Journal of Educational Administration, 35(5), 428-438.

Ra'is, D. U. (2017). Peta inklusi sosial dalam regulasi desa. Reformasi, 7(2), 88-106. 